Research Article

\title{
A study on assessment of knowledge on biomedical waste management among health care workers of Malabar Medical College Teaching Hospital, Calicut, Kerala, India
}

\author{
Ananthachari K. R.*, Divya C. V. \\ Department of Community Medicine, Malabar Medical College Hospital and Research Centre, Kerala, India
}

Received: 14 August 2016

Accepted: 19 August 2016

*Correspondence:

Dr. Ananthachari K. R.,

E-mail: ananthachari11@gmail.com

Copyright: $\odot$ the author(s), publisher and licensee Medip Academy. This is an open-access article distributed under the terms of the Creative Commons Attribution Non-Commercial License, which permits unrestricted non-commercial use, distribution, and reproduction in any medium, provided the original work is properly cited.

\begin{abstract}
Background: Health care institutions and hospitals generate biomedical waste which can introduce various infections and injuries to the healthcare workers, patients and harm the surrounding environment. For proper management of biomedical waste Government of India has introduced the biomedical waste management and Handling rules in 1998, unfortunately health care workers awareness regarding biomedical waste segregation, handling and management is minimal hence, the study addresses the issues related to it.

Methods: This cross sectional study was conducted in the month of July 2016 among health care workers at Malabar Medical College Hospital and Research Centre, Calicut, India. A pre-tested, semi-structured questionnaire was used to elicit the various information like collection, segregation and disposal of biomedical waste.

Results: 567 health care workers were interviewed.44.3\% (251) opined correctly that biomedical waste should not be kept more than 48 hours at hospital settings. 61.6\% (349) opined waste sharps should be disposed in white/blue puncture proof containers.89.6\% (508) knew about HIV, hepatitis B and hepatitis C are common infections transmitted due to improper biomedical waste management. 60.5\% (345) and $61 \%$ (346) opined that human anatomical waste and pads, cottons, dressings should be disposed in yellow bags, respectively. $70.7 \%$ (401) were fully immunised against hepatitis B. 29.8\% (169) had received training on biomedical waste management.

Conclusions: Knowledge regarding biomedical waste disposal among nursing staff is satisfactory compared to other health care workers, adequate training among health care workers can improve the biomedical waste management and handling practices at hospital settings.
\end{abstract}

Keywords: Biomedical waste, Knowledge, Segregation

\section{INTRODUCTION}

"Biomedical waste" has been defined as " any waste that is generated during diagnosis, treatment or immunization of human beings or animals or in the research activities pertaining to or in the production or testing of biologicals and includes categories mentioned in schedule I of the government of India's biomedical waste (Management and Handling) Rules 1998". ${ }^{1}$
Health care Institutions and various hospitals, diagnostic centres, blood banks, dental centres and research centres produce a variety of waste like dressing material, cotton pads, anatomical body parts, plastic disposal items, needles, drugs, chemicals, food items, intravenous tubings, canula and catheter. Among these, infectious and sharp components become great threat to the health care workers and people associated with handling these waste. Approximately, more than three-fourth of the health care wastes are nonhazardous while the remaining proportion is hazardous and World health organisation reports $20 \%$ 
of total waste generated by health care activities are hazardous. Many pathogens have been documented to be transmitted by during Biomedical Waste Management (BMW) handling and segregation and disposal of which, Human Immunodeficiency Virus (HIV), hepatitis B Virus (HBV), hepatitis C Virus (HCV) are often implicated. ${ }^{2-5}$

The ministry of environment and forests has promulgated the Biomedical Waste Management and Handling Rules in 1998 for improving the overall waste management of health care facilities in India. Awareness of biomedical waste management among health care workers and public is necessary and it is the responsibility of the health care facility and health care providers to safeguard the health of workers who are involved in handling, transportation and disposal of biomedical waste, so proposed study identifies the information regarding the awareness of biomedical waste management and handling practices at hospital setting. ${ }^{6}$ The objective of the study was to assess the knowledge about Biomedical Waste Management among health care workers in Malabar medical college teaching tertiary care hospital, Calicut, India.

\section{METHODS}

This cross-sectional study was conducted among all the health care workers at Malabar Medical College Hospital and Research Centre from July $1^{\text {st }}$-July $31^{\text {st }} 2016$. Among 586 health care workers, 567 health care workers consented to participate in the study which consisted of 209 nursing staff, 147 doctors, house surgeons (127) and lab technicians (84) and they were selected randomly using table of random numbers and interviewed using a pretested, semi-structured questionnaire in the local language ( Malayalam) after obtaining written consent. Various information like collection, segregation and disposal of biomedical waste management were elicited from the study group. The data was entered in Microsoft Excel 7 and analysed using Statistical methods like percentages, and chi square test with the help of Statistical Package for Social Sciences (SPSS) version 21.

\section{Inclusion criteria}

- $\quad$ Those who are consenting for the study.

- Those who are working in medical field for more than 3 months.

\section{Exclusion criteria}

- Those who are not available at the time of study

\section{RESULTS}

Among 586 health care workers, a total of 567 were consented to participate in the study, of which 209 were nursing staff, 147 doctors, 127 house surgeons and 84 were laboratory technicians.

$42.8 \%$ (243) knew that biomedical waste management and handling rules promulgated in the year 1998, of which $16.2 \%$ (92) nursing staffs, 9.8\% (56) doctors, $10.1 \%$ (61) interns and $5.9 \%$ (34) lab technicians correctly answered. $44.3 \%$ (251) correctly opined that biomedical waste should not be kept at hospital setting beyond $48 \mathrm{hrs}$, of which $15.5 \%$ (88) nursing staffs, $14.6 \%$ (83) doctors, $7.6 \%$ (44) interns and $6.3 \%$ (36) were lab technicians respectively. $73.8 \%$ (419) knew that pollution control board will regulate biomedical waste management and handling practices, of which $29.9 \%$ (170) nursing staffs, $17.8 \%$ (101) doctors, $17.8 \%(101)$ interns and $8.2 \%$ (47) were lab technicians.

$37.6 \%$ (213) correctly opined that around $10-20 \%$ of the waste generated from the hospitals is infectious waste, in that $12.6 \%$ (72) nursing staffs, $8.9 \%$ (51) doctors, $9.8 \%$ (56) interns and $5.9 \%$ (34) were lab technicians. A total of $89.6 \%$ (508) of them opined that the infections like HIV, hepatitis $\mathrm{B}$ and hepatitis $\mathrm{C}$ can be transmitted during collection, segregation, transportation and treatment of biomedical waste management of which $32.8 \%$ (186) nursing staffs, $24.8 \%$ (141) doctors, $20.5 \%$ (116) interns and $11.5 \%$ (65) were lab technicians (Table 1).

Table 1: Knowledge regarding the general information on biomedical waste management among health care workers.

\begin{tabular}{|ll|llll|}
\hline General information & Doctors & Nursing stafi & Interns & Lab technicians & Total \\
\hline BMWrules-1998 & $9.8 \%(56)$ & $16.2 \%(92)$ & $10.1 \%(61)$ & $5.9 \%(34)$ & $42.8 \%(243)$ \\
\hline BMW regulation & $17.8 \%(101)$ & $29.9 \%(170)$ & $17.8 \%(101)$ & $8.2 \%(47)$ & $73.8 \%(419)$ \\
\hline $\begin{array}{l}\text { Percentage of BMW } \\
\text { generation at hospital }\end{array}$ & $8.9 \%(51)$ & $12.6 \%(72)$ & $9.8 \%(56)$ & $5.9 \%(34)$ & $37.6 \%(213)$ \\
\hline BMW keeping duration & $14.6(83)$ & $15.5 \%(88)$ & $7.6 \%(44)$ & $6.3 \%(36)$ & $44.3 \%(251)$ \\
\hline $\begin{array}{l}\text { Common infections } \\
\text { transmitted during } \\
\text { handling }\end{array}$ & $24.8 \%(141)$ & $32.8 \%(186)$ & $20.5 \%(116)$ & $11.5 \%(65)$ & $89.6 \%(508)$ \\
\hline
\end{tabular}

(BMW- Biomedical waste management, $\mathrm{N}=567, \mathrm{p}<0.05$ )

Observed difference was statistically significant hence, Overall general information regarding the biomedical waste management was more among nursing staff followed by interns and doctors $(\mathrm{p}<0.05)$. 


\section{Biomedical waste disposal in colour code bins}

Majority of them $88.5 \%$ ( 502) opined that general waste generated at hospital settings should be disposed in green colour bins of which $32.1 \%$ (182) nursing staffs $20.8 \%$ (118) interns, $22.9 \%$ (130) doctors, and $12.7 \%$ (72) laboratory technicians opined correctly.

$60.8 \%$ (346) opined that human anatomical waste should be disposed in yellow bins of which $21.2 \%$ (120) nursing staffs, $15.5 \%$ (88) interns, $14.9 \%$ (85) doctors, and $9.2 \%$ (52) laboratory technicians believed that it should be disposed in yellow bins. $27.5 \%$ (156) of them had misconception that human anatomical waste should be disposed in red bins.

$61.6 \%$ (349) knew that waste sharps should be disposed in white puncture proof containers of which $25.7 \%$ (146) nursing staffs, $16.3 \%$ (92) interns, $13.9 \%$ (79) doctors, and $5.6 \%$ (32) laboratory technicians opined correctly (Figure 1).

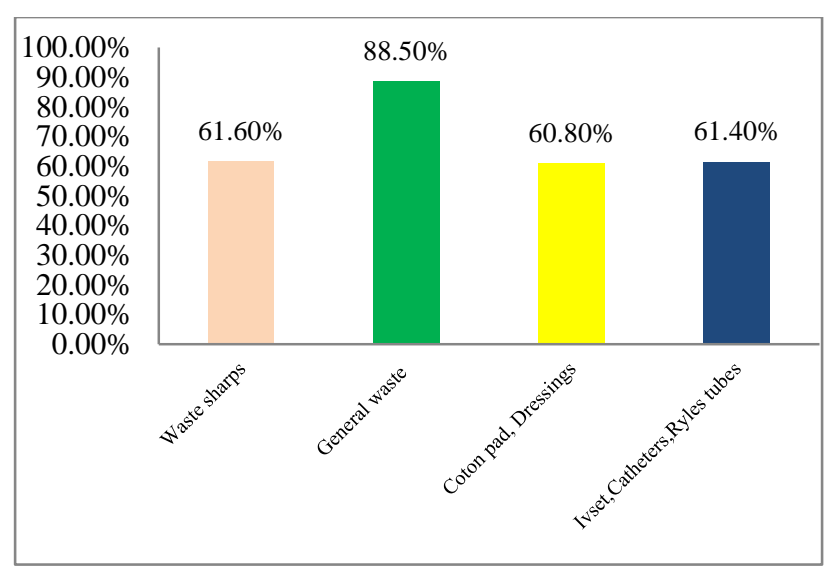

Figure 1: Knowledge regarding biomedical waste disposal in colour bins among health care workers.

$60.8 \%$ (345) believed that cotton pads, dressings should be disposed in yellow bins of which $21.2 \%$ (120) nursing staffs, $15.6 \%$ (88) interns, $14.9 \%$ (85) doctors, and $9.2 \%$ (52) laboratory technicians opined correctly (Table 2).

Table 2: Knowledge regarding disposal of biomedical waste in various colour coded bins among heath care workers.

\begin{tabular}{|lllllll|}
\hline $\begin{array}{l}\text { BMW disposal in } \\
\text { bins }\end{array}$ & $\begin{array}{l}\text { Colour code } \\
\text { bins }\end{array}$ & Doctors & Nursing staff & Interns & $\begin{array}{l}\text { Lab } \\
\text { technicians }\end{array}$ & Total \\
\hline $\begin{array}{l}\text { General waste } \\
\text { Human anatomical } \\
\text { waste }\end{array}$ & Yreen & $22.9 \%(130)$ & $32.1 \%(182)$ & $20.8 \%(118)$ & $12.7 \%(72)$ & $88.5 \%(502)$ \\
\hline Waste sharps & $\begin{array}{l}\text { White puncture } \\
\text { proof containers }\end{array}$ & $13.9 \%(79)$ & $25.7 \%(146)$ & $16.3 \%(92)$ & $5.6 \%(32)$ & $61.6 \%(349)$ \\
\hline $\begin{array}{l}\text { Cotton pads, } \\
\text { dressings }\end{array}$ & Yellow/red & $14.9 \%(85)$ & $21.2 \%(120)$ & $15.6 \%(88)$ & $9.2 \%(52)$ & $60.8 \%(345)$ \\
\hline $\begin{array}{l}\text { IV set canula, } \\
\text { tubings, catheter }\end{array}$ & Blue & $12.7 \%(72)$ & $26.5 \%(150)$ & $15.8 \%(90)$ & $6.4 \%(36)$ & $61.4 \%(348)$ \\
\hline
\end{tabular}

( BMW- Biomedical waste management, $\mathrm{N}=567, \mathrm{p}<0.05$ ).

$61.4 \%$ (348) opined that intravenous set canula, catheters and Ryles tube should be disposed in blue bins, of which $26.5 \%$ (150) nursing staffs, $15.8 \%$ (90) interns, $12.7 \%$ (72) doctors, and $6.4 \%$ (36) laboratory technicians believed that it should be put in blue bins. The observed difference among health care workers regarding the disposal of biomedical waste was statistically significant $(p<0.05)$ indicating that the knowledge was more among the nursing staff in comparison with the interns, doctors and laboratory technicians.

\section{Immunisation against hepatitis B}

$86.9 \%$ (493) have received one or two doses of hepatitis B of which $70.7 \%$ (401) were fully immunised against hepatitis B. Of the fully immunised $22.1 \%$ (125) were nursing staff, $9.5 \%$ (54) laboratory technicians, $19.4 \%$ (110) interns and $19.7 \%$ (112) doctors, respectively.

\section{Training}

$29.8 \%$ (169) have received training for biomedical waste management in last 5 year period in that $20.8 \%$ (115) were nursing staff, 2.9\%(17) laboratory technicians, $3.7 \%$ (21) interns and $2.8 \%$ (16) were doctors, respectively.

\section{DISCUSSION}

Majority of them knew that biomedical waste management and handling rules was enacted in 1998 and approximately $73.8 \%$ knew that pollution control board will regulate biomedical waste management and handling practices, knowledge was more among nursing staff 
compared to doctors, interns and laboratory technicians this is due to lack of adequate training. Similar findings have been reported from study conducted by Bhagawati $\mathrm{G}$ et al, on awareness and practices regarding bio-medical waste management among health care workers in a tertiary care hospital in Delhi. ${ }^{7}$ However this was in contrast with findings reported in a study by Narang et al, opined knowledge was more among the doctors followed by nurses and other paramedical staffs. ${ }^{8}$ Where as a study done by Sharma A et al, at Jaipur on health care personnel regarding knowledge of biomedical waste management handling rules and legislation among nurses was surprisingly $36.0 \%$. $^{9}$

In this study $61.6 \%$ (349) knew that waste sharps should be disposed in white puncture proof containers of which $25.7 \%$ (146) nursing staffs, $16.3 \%$ (92) interns, $13.9 \%$ (79) doctors, and 5.6\% (32) laboratory technicians opined correctly. A study by Joseph L et al, on the awareness of biomedical waste management and handling practices among healthcare workers in a tertiary teaching hospital at Tamilnadu reported $90 \%$ knowledge regarding disposal of waste sharps. ${ }^{10}$

A study done by Das SK et al, on Awareness and practice of biomedical waste management among healthcare providers in a tertiary care hospital of West Bengal revealed that knowledge regarding waste sharps disposal was $31.3 \%$ among health care providers. ${ }^{11}$

Health care workers who handles waste are at high risk of getting fatal diseases like hepatitis B and C and HIV by contaminated needles and other waste sharps. ${ }^{12}$ Hence, knowledge regarding the transmission of all these infections and immunisation against hepatitis B is necessary among health care workers. Majority (89.0\%) of them opined correctly that the diseases like HIV, hepatitis $\mathrm{B}$ and hepatitis $\mathrm{C}$ can be transmitted during the biomedical waste collection, segregation and disposal, while similar findings were reported in the study by Indupalli AS et al, at Khaja Banda Nawaz institute of medical sciences, Kalburgi, Karnataka, India. ${ }^{13}$

In this study $70.7 \%$ were fully immunised against hepatitis B of which $22.1 \%$ (125) nursing staff, 9.5\% (54) laboratory technicians, $19.4 \%$ (110) interns and $19.7 \%$ (112) doctors. A study done by Kumar M et al, on health care workers in a tertiary care hospital Haldwani, Nainital reports $31.0 \%$ of the health care workers were unvaccinated against hepatitis $\mathrm{B} .^{14}$

A study by Mathur $\mathrm{V}$ et al, on knowledge, attitude and practices about biomedical waste management among healthcare personnel opined overall colour coding and waste segregation at source was found to be better among nurses as compared to doctors which was similar findings were reported from our study. ${ }^{15}$
Deo $\mathrm{D}$ et al, in their study opined nurses and lab technicians had better knowledge (90\%) than medical staff like doctors $(80.6 \%)$ and Saini $\mathrm{S}$ et al., also opines nursing staff had fair knowledge and positive attitude regarding health care waste segregation. ${ }^{16,17}$

Many studies opined that necessity of effective practical training and adequate theoretical knowledge is required among both medical and paramedical health care workers for overall improvement of biomedical waste management and handling practices. ${ }^{18,19}$

\section{CONCLUSION}

Knowledge regarding the collection, segregation, rules, and disposal of biomedical waste management is more among nursing staff compared to other health care workers. Hence, emphasis on adequate training is required among health care workers for the safe handling and disposal of biomedical waste management.

\section{ACKNOWLEDGEMENTS}

Authors would like to acknowledge our beloved Professor and Head, Dr. Shivashakarappa for support and motivation.

\section{Funding: No funding sources}

Conflict of interest: None declared

Ethical approval: The study was approved by the Institutional Ethics Committee

\section{REFERENCES}

1. National guidelines on hospital waste management based up on the bio-medical waste (Management and Handling) Rules, 1998. Government of India, Ministry of Health and Family Welfare (MoHFW).New Delhi: MoHFW; 2002.

2. Pruss A, Cirouit E, Rushbrook P: Definition and characterization of health-care waste in safe management of waste from health-care activities. Geneva:WHO;1999.

3. Coker A, Sangodoyin A, Sridhar M, Booth C, Olomolaiye P, Hammond F. Medical waste management in Ibadan, Nigeria: obstacles and prospects. Waste Manag. 2009;29(2):804-11.

4. Park K. Hospital waste management. In: Park K, editor. Textbook of Preventive and Social Medicine. 23rd ed. Banarasidas Bhanot publishers Jabalpur, India; 2015;789-90.

5. WHO fact Sheet No 253. Waste from health care activities. Available at http: //www.who.int /mediacentre/ factsheets/fs253/en/. Accessed on $10^{\text {th }}$ August 2016.

6. Sharma S. Awareness about bio-medical waste management among health care personnel of some important medical centers in Agra. Int $\mathbf{J}$ Environmental Sci Development. 2010;1(3):252-5. 
7. Bhagawati G, Nandwani S, Singhal S. Awareness and practices regarding bio-medical waste management among health care workers in a tertiary care hospital in Delhi. Indian J Med Microbio. 2015;33(2):580-2.

8. Narang RS, Manchanda A, Singh S, Verma N, Padda S. Awareness of biomedical waste management among dental professionals and auxiliary staff in Amritsar, India. Oral Health Dent Manag. 2012;11:162-8.

9. Sharma A, Sharma V, Sharma S, Singh P. Awareness of biomedical waste management among health care personnel in Jaipur, India. Oral Health Dent Manag. 2013;12(1):32-40.

10. Joseph L, Paul H, Premkumar J, Rabindranath, Paul R, Michael JS. Biomedical waste management: study on the awareness and practice among healthcare workers in a tertiary teaching hospital. Indian J Med Microbiol. 2015;33(1):129-31.

11. Das SK. Awareness and practice of biomedical waste management among healthcare providers in a tertiary care hospital of West Bengal, India. Int Journal Med Public Health. 2016;6(1):19-25.

12. Suryakantha AH, Management of hospital waste. In: Suryakantha AH, Editor. Community medicine with recent advances.4th ed. Jaypee brothers medical publishers Ltd. New Delhi. 2017:93.

13. Indupalli AS, Motakpalli K, Giri PA, Ahmed BN. Knowledge, attitude and practices regarding biomedical waste management amongst nursing staff of Khaja Banda Nawaz institute of medical sciences, Kalburgi, Karnataka. National J Community Med. 2015;6(4):562-65.
14. Kumar M, Singh RK, Varshney U, Rawat V. Awareness and practices about bio-medical waste among Health care workers in Tertiary care hospital of Haldwani, Nainital. Natl J Med Res. 2015;5(1):47-51.

15. Mathur V, Dwivedi S, Hassan MA, Misra RP. Knowledge, attitude and practices about biomedical waste management among healthcare personnel. a cross-sectional study. Indian J Community Med. 2011;36(2):143-5.

16. Deo D, Tak SB, Munde SS. A study of knowledge regarding biomedical waste management among employees of a teaching hospital in rural area. $\mathbf{J}$ Indian Soc Hospital Waste Management. 2006;5(1):12-6.

17. Saini S, Nagarajan SS, Sharma RK. Knowledge, attitude and practices of bio-medical waste management amongst staff of a tertiary level hospital in India. J Academy Hospital Administration. 2005;17(2):1-12.

18. Mohapatra A, Gupta M, Shivalli S, Mishra CP, Mohapatra SC. Biomedical waste management practices of doctors: An online snapshot. Natl J Community Med. 2012;3:227-31.

19. Pandit NB, Mehta HK, Kartha GP, Choudhary SK. Management of bio-medical waste: Awareness and practices in a district of Gujarat. Indian J Public Health. 2005;49:245-7.

Cite this article as: Ananthachari KR, Divya CV. A study on assessment of knowledge on biomedical waste management among health care workers of tertiary care hospital. Int J Community Med Public Health 2016;3: 2409-13. 